\title{
Level of dependence on video games in adolescents from family and non-family homes in the South of Veracruz, Mexico
}

\section{Nivel de dependencia a los videojuegos en adolescentes de hogares familiares y no familiares del Sur de Veracruz, México}

\author{
OSORIO-PÉREZ, Dorian Jared† \& BLANCO-ENRÍQUEZ, Francisca Elvira*
}

Escuela de Enfermería Gotinga, Headquarters Coatzacoalcos, Veracruz, Mexico.

ID $1^{\text {st }}$ Author: Dorian Jared Osorio-Pérez / ORC ID: 0000-0002-4783-3021

ID $1^{\text {st }}$ Coauthor: Francisca Elvira Blanco-Enríquez / ORC ID: 0000-0001-6802-7486, CVU CONACYT ID: 785171

DOI: 10.35429/JEHW.2020.7.4.24.31

Received July 25, 2020; Accepted December 30, 2020

\begin{abstract}
The use of video games is a global problem that mainly involves young and adolescent population. Methodology: Study with a quantitative approach, non-experimental design, cross-sectional, descriptive type. Universe: 885 adolescents. Sample: 264 students. Sampling: stratified random. Instruments: Personal and Sociodemographic Data Card (CDPS) and the Video Game Dependence Test (TDV) (Chóliz and Marco, 2011). The study adhered to the provisions of the General Health Law on Health Research. For data analysis, it was used the SPSS 25. Results: $83.3 \%$ said they played video games in the last year, while $16.7 \%$ denied. Of the current players, half $(50.4 \%)$ of the young people who have played in the last year mention playing alone, mainly from a non-family home. The cell phone is the most used device for video games, with a little more than half $(52.7 \%)$ of participants who reported their use, of which all belong to a family home. In terms of dependence on video games, $43.2 \%$ was light, $35 \%$ medium, $17.7 \%$ abuse, and $4.1 \%$ pathological. Pathological gamblers belong to family homes.
\end{abstract}

Dependence on video games, Adolescent, Home

\begin{abstract}
Resumen
El uso de videojuegos es un problema mundial principalmente en población joven y adolescente. Metodología: Estudio de enfoque cuantitativo, diseño no experimental, corte transversal, tipo descriptivo. Universo: 885 adolescentes. Muestra: 264 estudiantes. Muestreo: probabilístico, aleatorio estratificado. Instrumentos: Cédula de Datos Personales y Sociodemográficos (CDPS) y el Test de Dependencia de videojuegos (TDV) (Chóliz y Marco, 2011). El estudio se apegó a lo establecido en la Ley General de Salud en Materia de Investigación para la Salud. Para el análisis de datos se utilizó el SPSS 25. Resultados: El 83.3\% afirmó haber jugado videojuegos en el último año, mientras que $16.7 \%$ lo negó. De los jugadores actuales, la mitad (50.4\%) de los jóvenes menciona jugar solo, principalmente de un hogar no familiar. El celular es el dispositivo más utilizado para los videojuegos, con un poco más de la mitad $(52.7 \%)$ de participantes que reportaron su uso, de los que todos pertenecen a hogar familiar. En nivel de dependencia a los videojuegos, $43.2 \%$ fue ligero, $35 \%$ medio, $17.7 \%$ abuso y $4.1 \%$ patológico. Los jugadores patológicos pertenecen a hogares familiares.
\end{abstract}

Dependencia a los videojuegos, Adolescente, Hogar

Citation: OSORIO-PÉREZ, Dorian Jared \& BLANCO-ENRÍQUEZ, Francisca Elvira. Level of dependence on video games in adolescents from family and non-family homes in the South of Veracruz, Mexico. Journal-Health Education and Welfare. 2020. 4-7:24-31.

\footnotetext{
* Correspondencia del Autor (Email: franblancoe@ hotmail.com)

$\dagger$ Researcher contributing as first author.
} 


\section{Introduction}

In recent years, the use and abuse of Information and Communication Technologies (ICT) is a subject that arouses enormous interest among the world population. Technologies such as the internet, mobile phones and video games represent very useful tools in everyday life, however, there are also certain drawbacks, in which their own design is likely to affect control capacity, which, along with other Personal and environmental factors, facilitate its abusive or inappropriate use, generating the so-called "behavioral addictions", related to various problems for the health of the affected person and those around him (Marco and Chóliz, 2017).

In disorders due to addictive behaviors, the World Health Organization (WHO) in its new edition of the International Classification of Diseases (ICD-11), includes video game disorder for the first time. Video game use disorder can be diagnosed when, over a period of at least 12 months, a behavior characterized by loss of control over the time spent playing is displayed, the highest priority that the game acquires over other interests and activities and the continuation of this behavior despite its negative consequences (WHO, 2019).

Studies indicate that the prevalence of video game use disorder in ranges between $1 \%$ and $10 \%$ in Europe and North America (WHO, 2019). In Europe, more than 206 million video players are reported, in a population of more than 367 million people with internet access. In Spain, 16.8 million video gamers are present, people of all ages and with an increasing presence of women (Asociación Española de Videojuegos, 2018).

In the United States, the Entertainment Software Association (2020), reports that more than 214 million people in the United States play video games for an hour or more per week. $75 \%$ of all american households have at least one person who gambles. $64 \%$ of American adults and $70 \%$ of those under the age of 18 play video games regularly.
In Latin America, Mexico is reported as the first consumer of video games and worldwide it occupies the 12th place, an important phenomenon in the Mexican Republic, since it is estimated that half of the population uses them, in the country the use of video games is considered a space for junk food advertisers, although it could also be a tool to promote healthy habits (Universidad Nacional Autónoma de México [UNAM], 2020).

The 2018 National Audiovisual Content Consumption Survey, reports that $21 \%$ of those interviewed said they play video games, with the cell phone being the most used device with $58 \%$. Regarding the use of the network and video games, $37 \%$ used to play online games. About who they play with, $43 \%$ play alone. $11 \%$ of the participants have a video game console (Instituto Federal de Telecomunicaciones [IFT], 2018).

In the National Survey on the Availability and Use of Information Technologies in Homes (ENDUTIH), it was reported that $6.2 \%$ of internet users, according to the connection device, connect through a video game console (Instituto Nacional of Statistics and Geography [INEGI], 2018).

For its part, the Government of the State of Mexico (2017), indicates that the statistics of video game addicts reflect a higher prevalence of young men, between 10 and 35 years of age. In general, they suffer from difficulties in social integration and interaction. Although online games allow sharing and competition, the virtual world leads them to protect themselves more and preserve isolation.

In this sense, video games, with certain visual and auditory qualities, are attractive mainly for young people, as they include multiple entertainment functions and even the possibility of interacting with several players simultaneously from any device (Andrade, Carbonell \& López, 2018). 
The adolescent population is considered highly vulnerable to dependence on video games, since these are characterized by "catching" those who make use of it, and that is where it is necessary to consolidate the personal and social identity of each person to a greater extent. individual, being necessary to promote critical and reflective thinking around the use of this technology, with which users can see themselves projected onto some of the people in which they interact in the video game (Ameneiros and Ricoy, 2015).

Likewise, the use of video games among adolescents can affect school performance when, due to playing, the completion of schoolwork is neglected, hours of sleep are sacrificed or they are exposed to too many hours in front of the video game without respecting the necessary rest periods . In other words, it seems that the behavior involved in video games can become pathological depending on the intensity or frequency invested in it and the degree of interference in the family, social and / or school relationships of the people involved (Fuentes and Pérez, 2015).

In recent years, the number of works on video games in adolescents has increased significantly, involving mental health and social environment variables, due to the development and search for identity and personality that characterizes the adolescent. The research on the use of video games that analyzes the home and the family possibly allows to know more about the dynamics of interaction of the adolescent according to his self-realization as an individual.

It is worth mentioning that the use and abuse of video games among the adolescent population is considered an emerging problem recognized by the entire scientific field, although the nursing professional is of great importance for the care and prevention of addictions, which can contribute to reducing the problem by promoting preventive actions so that young people know the effects and consequences of the different uses of video games, identifying the possible benefits of a controlled use, as well as its contrasts with the mental repercussions that affect the addict, his family and community

\section{Objective}

Determining the level of video game dependence in adolescents from family and non-family homes in southern Veracruz, Mexico.

\section{Methodology}

The study was of quantitative approach, nonexperimental design, cross-sectional, descriptive type. The universe was composed of 885 adolescents from a public high school belonging to family and non-family homes in southern Veracruz, Mexico.

The sample was 264 adolescents, calculated with the statistical package STATS. The sampling was of probability class, of stratified random type, in which all the individuals had the same opportunity to be chosen according to each segment of the population (grade and group).

The participating adolescents were found enrolled in a public high school in the South of Veracruz, in the February-July 2020 school period, of any sex, who agreed to participate in the study during the month of February when the corresponding research instruments were applied.

A Personal and Sociodemographic Data Card (CDPS) was used, prepared by the authors of this study that included exploratory questions on age, sex, religion, marital status, occupation, shift, semester, type of household, history of video game use and alcohol consumption.

For the present study, the types of household proposed by the National Institute of Statistics and Geography of Mexico [INEGI] (2015) were considered, which states that the nuclear home is where the father, mother and children or only mother live either the father with children, or a couple who live together and have no children also constitutes a nuclear home; the extended home is made up of a nuclear home plus other relatives (uncles, cousins, brothers, in-laws, etc.); a composite household is one made up of a nuclear or extended household, plus people who are not related to the head of the household; the oneperson household is one made up of a single person; and the co-resident household is made up of two or more unrelated people. 
Likewise, the Video Game Dependence Test (TDV) was applied, prepared by Mariano Chóliz and Clara Marco in 2011, a diagnostic instrument for video game dependence based on the main DSM-IV diagnostic criteria for substance dependence disorder. It consists of 25 items, with a response scale from 0 to 4 . It has four dimensions: abstinence, abuse and tolerance, problems caused by video games and difficulty in control (Marco and Chóliz, 2017).

The instrument is scored according to the level of dependence on video games: Light use ( 1 to 25 points) Medium use (26 to 50 points) Abuse (51 to 75 points) Pathological use (76 to 100 points). It reports a Cronbach's alpha of 0.94 in other investigations, so it can be considered an instrument with satisfactory psychometric characteristics (Marco and Chóliz, 2017).

When analyzing the internal consistency of the instrument applied in this study, the TDV presented a Cronbach's Alpha of $\alpha=0.954$, which is acceptable according to Hernández, Fernández and Baptista (2014).

This research adhered to the provisions of the General Health Law on Health Research, Last Reform DOF-2014 (Congress of the Mexican Union, 2014).

For data analysis, the Statistical Package for the Social Sciences (SPSS) version 25 was used to obtain descriptive statistics data such as frequencies and percentages.

\section{Results}

In sociodemographic data of the participating adolescents (Table 1), 51.9\% were women and $48.1 \%$ men, with a mean age of 16.21 years $(\mathrm{SD}=0.958)$, with a minimum of 15 years and a maximum of 19 years. Regarding the marital status, $63.6 \%$ were single, followed by $32.6 \%$ in a courtship, $2.7 \%$ married and $1.1 \%$ common-law union. In religion, more than half of the young people reported being Catholic with $64.4 \%$, followed by $22.8 \%$ who did not profess any religion, 6.8\% Christian and 6\% from any other religion. Regarding occupation, 93.6\% of young people dedicated themselves exclusively to studying, while $6.4 \%$ study and work.

\begin{tabular}{|l|r|r|}
\hline \multicolumn{2}{|c|}{$\boldsymbol{f}$} & \multicolumn{1}{c|}{$\%$} \\
\hline Gender & & \\
\hline Male & 127 & 48.1 \\
\hline Female & 137 & 51.9 \\
\hline Marital status & & \\
\hline Single & 168 & 63.6 \\
\hline Engagement & 86 & 32.6 \\
\hline Married & 7 & 2.7 \\
\hline Free Union & 3 & 1.1 \\
\hline Religion & & \\
\hline Does not profess any & 60 & 22.8 \\
\hline Catholic & 170 & 64.4 \\
\hline Christian & 18 & 6.8 \\
\hline Jehovahs Witness & 4 & 1.5 \\
\hline Pentecost & 1 & 0.4 \\
\hline Presbyterian & 3 & 1.1 \\
\hline Mormon & 4 & 1.5 \\
\hline Adventist & 3 & 1.1 \\
\hline Protestantism & 1 & 0.4 \\
\hline Occupation & & \\
\hline Exclusive dedication student & 247 & 93.6 \\
\hline Study and work & 17 & 6.4 \\
\hline
\end{tabular}

Table 1 Sociodemographic data Source: $C D P S$

Regarding the school data, $58.3 \%$ of the participants were from the morning shift and $41.7 \%$ the afternoon shift, distributed in three current semesters, $36.3 \%$ second, $34.5 \%$ fourth and $29.2 \%$ sixth.

According to the type of household, in the first place $54.2 \%$ were found with a nuclear home, in second place, $42 \%$ of the extended one, third with $2.3 \%$ composite, fourth with $1.1 \%$ in a one-person household and lastly $0.4 \%$ correcident.

When asked about the use of video games in the last (current) year, there was a higher percentage of young people who claimed to have played video games with $83.3 \%$ ( $\mathrm{f}=$ 220 ), while $16.7 \%$ ( $f=44$ ) denied it. The average of hours dedicated to the use of video games in a typical day of current players was 3.28 hours $(\mathrm{SD}=2.91)$, with a minimum of 1 hour and a maximum of 24 hours. In alcohol consumption, half of the current players $(50 \%)$ affirmed the consumption of alcohol in the last year, and the other half (50\%) denied it.

Regarding the data on video game use of current players, when asked about game days, the total of adolescents reported playing primarily every day with $35.5 \%$, followed by $23.6 \%$ one day a week and $18.6 \%$ two days. When analyzing by type of household, of the adolescents who play every day, $40 \%$ belong to a composite family home, subsequently $37.3 \%$ nuclear, and with the same percentage the players from an extended family home and nonfamily one-person, with $33.3 \%$ in both. 
Regarding the main reason for using video games, the total of players in the last year mainly referred to playing for entertainment with $39.5 \%, 22.7 \%$ fun and $15.9 \%$ distraction. By type of household, in the main reason for gambling for entertainment, all (100\%) of adolescents belong to a non-family home, followed by $60 \%$ to a composite family home and $41.7 \%$ to the extended family.

Regarding the main place of video game use (Table 2), close to the total of current adolescent gamers $(95.9 \%)$ indicated the home as the first place to play, with $100 \%$ of young people who are a composite family home and a co-resident non-family, followed $96.9 \%$ of extended family home.

In relation to who frequently plays video games with (Table 3), half (50.4\%) of all young current players mention playing alone, in second place $26 \%$ with school friends and in third place $13.6 \%$ with family members. Of the adolescents who frequently play alone, the highest percentages are from a non-family home, with $100 \%$ co-occurring and $66.7 \%$ oneperson, while $60 \%$ are from a composite family home.

Regarding the primary device where video games are used (Table 4), a little more than half $(52.7 \%)$ of the total of participants who have played in the last year reported using the cell phone for the game, followed by $29.1 \%$ the console and $15 \%$ computer. Of the young people who mainly use cell phones for video games, all belong to a family home, $80 \%$ composite, $55.7 \%$ nuclear and 50\% extended.

When analyzing the level of dependence on video games (Table 5), of the total number of current adolescent gamers, $43.2 \%$ had a slight level of dependence, followed by $35 \%$ medium, $17.7 \%$ abuse and $4.1 \%$ pathological. By type of household, the pathological players belong to family households, $6.1 \%$ nuclear and $2.1 \%$ extended; abused players have a higher percentage in non-family homes, with $100 \%$ in co-resident; In terms of dependence on medium video games, the highest percentage is young people from a non-family home, with $100 \%$ one-person.

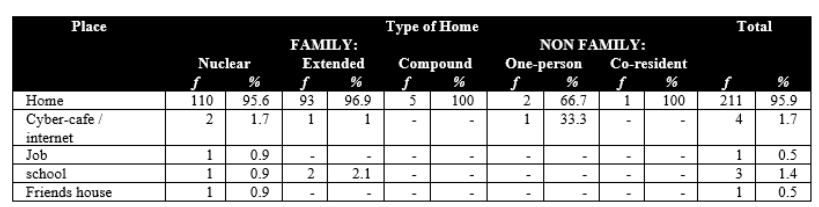

Table 2 Main place of video game use Source: $C D P S, T D V$

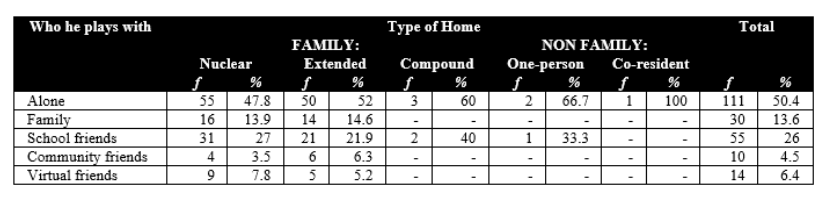

Table 3 With whom you frequently play video games Source: CDPS, TDV

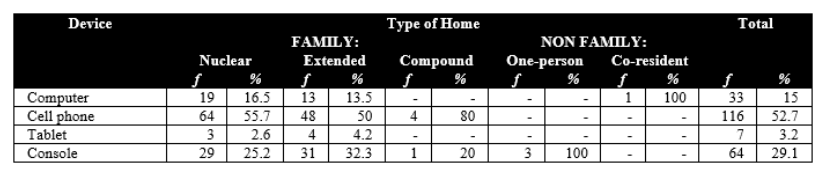

Table 4 Primary device where video games are used Source: CDPS, TDV

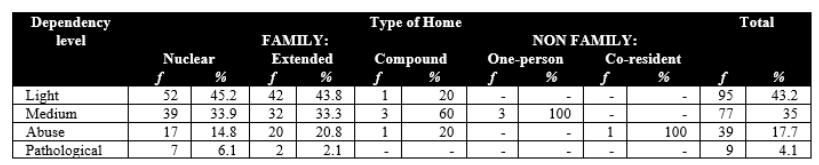

Table 5 Level of dependence on video games Source: CDPS, TDV

\section{Discussion}

In the present study, it was found that $83.3 \%$ of adolescents claimed to have played video games in the last year, a figure higher than that investigated nationally in the Mexican Republic by the Federal Institute of Telecommunications (2018) in the National Survey of Audiovisual Content Consumption 2018, which reported $21 \%$ of respondents who said they play video games, a worrying fact due to the high percentage of young people who found themselves as current players in the present research, which perhaps suggests an increase in the prevalence of the game in this vulnerable population.

It should be noted that it coincides with the study by García, Piqueras and Marzo (2017) in Spanish adolescents from Alicante who claimed to play video games with $82.9 \%$ and was similar to that found by Gómez, Devís and Molina (2020) in young Spanish adolescents with $96.8 \%$ who claimed to play. 
On the days of play per week, in the first place $35.5 \%$ of adolescents indicated playing every day, a higher percentage than that reported by Restrepo, Arroyave and Arboleda (2019) in adolescents from the municipality of La Estrella- Antioquia in Colombia, with $26 \%$ saying that they use video games every day, a finding that stands out for the possibility of creating a daily habit of using video games.

Regarding the preferred place to play, 95.9\% of the participants prefer home, which is similar to that reported by Restrepo, Arroyave and Arboleda (2019) in Colombian adolescents who point out that the use of video games is done almost exclusively at home with $81.49 \%$, which is striking as it is the place where adolescents can spend most of their free time if they are not involved in extracurricular or recreational activities that promote healthpromoting behaviors.

Regarding who plays video games with, mainly $50.4 \%$ of young people mention playing alone, similar to that reported by the Federal Telecommunications Institute (2018) in the National Survey of Audiovisual Content Consumption, with $43 \%$ of those interviewed playing alone, which is worrying because video games allow the possibility of interacting with multiple people at the same time and even with people from other countries, so perhaps the adolescent can be reflected and improve their social identity through video games.

The preferred device for the use of video games was the cell phone with $52.7 \%$, which coincides with the Federal Telecommunications Institute (2018) in the National Survey of Audiovisual Content Consumption that refer to the cell phone as the most used device with $58 \%$, which could perhaps increase the use of video games among adolescents because cell phone use is sometimes a trend among young people.

When analyzing the level of dependence on video games of current players, $43.2 \%$ was found to be light, $35 \%$ medium, $17.7 \%$ abuse and $4.1 \%$ pathological, which agrees with the study by Alave and Pampa (2018) in an educational institution state of Lima East of Peru, which reported a higher percentage of dependency of adolescents with low dependency with $45.5 \%$.
However, the percentage of young people with pathological dependence on video games in this study is higher than that found in adolescents by Andrade, Carbonell and López (2018) in Ecuador, Montero, Bogas, Barradas, Gómez and Chacón (2019) in Spain and by Oflu and Yalcin (2019) in Turkey, with 1.13\%, $2 \%$ and $1.6 \%$, respectively.

\section{Conclusions}

Participating adolescents showed a high prevalence of current video game use, which they refer to doing mostly every day at home, a place that may be common in the daily life of young people in development and in search of identity and personality, which increases the possibility of unlimited use where users can see themselves projected onto some of the people with whom they interact in the video game.

When asked about with whom they frequently play video games, half of the young people play alone, which mainly belong to nonfamily households, that is, that their household is made up of a single person or by two or more people without family relationships. worrying because video games have the possibility of interacting with several players simultaneously, which can be dependent for the user.

The primary device for the use of video games is the cell phone, where young people who use it refer to being from family homes, whether it is a nuclear, extended or compound home, that is, despite being surrounded by various people at home, the game Through this device, it perhaps offers greater practical entertainment qualities, which are visually and aurally attractive.

Regarding the level of dependence on video games, adolescents were reported in the four patterns, with a higher proportion in light use, although a pathological level and abuse were found among the participants. Young people with a level of pathological dependence belong to family homes, a worrying fact since this level may cause problems and family or couple discussions, decreased academic or personal performance, social isolation, anxiety and depression. 


\section{References}

Alave-Mamani, S. M. y Pampa-Yupanqui, S. N. (2018). Relación entre dependencia a videojuegos y habilidades sociales en estudiantes de una institución educativa estatal de Lima Este. Muro de la investigación, 3(2), 70-82.

https://doi.org/10.17162/rmi.v3i2.116270

Ameneiros, A. y Ricoy, M. (2015). Los videojuegos en la adolescencia: prácticas y polémicas asociadas. Estudios e Investigación en Psicología y Educación, (13), 1-6. DOI: 10.17979/reipe.2015.0.13.451.

Andrade, L., Carbonell, X. y López, V. M. (2018). Variables sociodemográficas y uso problemático de videojuegos en adolescentes ecuatorianos. Health and Addictions, 19(1), 110.

Asociación Española Videojuegos (AEVI) (2018). La industria del videojuego en España Anuario. Recuperado

de: http://www.aevi.org.es/web/wpcontent/uploads/2019/05/AEVI_Anuario_2018. pdf.

Asociación Software de Entretenimiento de Estados Unidos (2020). 2020 Essential Facts About the Video Game Industry. Recuperado de: https://www.theesa.com/esa-research/2020essential-facts-about-the-video-game-industry/.

Congreso de la Unión Mexicano (2014). Ley General de Salud en Materia de Investigación para la Salud, Última Reforma DOF-2014. Recuperado

de: http://www.diputados.gob.mx/LeyesBiblio//regl ey/Reg_LGS_MIS.pdf.

Fuentes, L. y Pérez, L. (2015). Los videojuegos y sus efectos en escolares de Sincelejo, Sucre (Colombia). Opción, 31 (6), 318-328.

García-Oliva, C., Piqueras, J. A. y Marzo, J. C. (2017). Uso problemático de internet, el móvil y los videojuegos en una muestra de adolescentes alicantinos. Salud y drogas, 17(2), 189-200.

Gobierno del Estado de México (2017). Adicción a los videojuegos. Recuperado de: https://salud.edomex.gob.mx/cevece/document os/difusion/tripticos/2017/Semana\%2032.pdf.
Gómez-Gonzalvo, F., Devís-Devís, J. y MolinaAlventosa, P. (2020). El tiempo de uso de los videojuegos en el rendimiento académico de los adolescentes. Comunicar, 28(65), 87-96. DOI https://doi.org/10.3916/C65-2020-08

Hernández, R., Fernández, C. y Baptista, L. (2014). Metodología de la Investigación (Sexta Edición). México, DF: McGraw Hill Education.

Instituto Federal de Telecomunicaciones (IFT) (2018). Encuesta Nacional de Consumo de Contenidos Audiovisuales 2018. Recuperado de:

http://www.ift.org.mx/sites/default/files/conteni dogeneral/medios-y-contenidos-

audiovisuales/encca18nacional.pdf.

Instituto Nacional de Estadística y Geografía (INEGI) (2015). Hogares. Recuperado de: http://cuentame.inegi.org.mx/poblacion/hogares .aspx?tema $=\mathrm{P}$.

Instituto Nacional de Estadística y Geografía (INEGI) (2018). Encuesta Nacional sobre Disponibilidad y Uso de las Tecnologías de la Información en los Hogares (ENDUTIH). Recuperado de: https://www.inegi.org.mx/contenidos/saladepre nsa/boletines/2018/OtrTemEcon/ENDUTIH201 8_02.pdf.

Marco, C. y Chóliz, M. (2017). Eficacia de las técnicas de control de la impulsividad en la prevención de la adicción a videojuegos. Terapia psicológica, 35(1), 57-69.

Montero-Duarte, A., Bogas, R., Barradas, J. M., Gómez, S. y Chacón-Cuberos, R. (2019). Análisis y relación entre el uso problemático de videojuegos y nivel de actividad física en adolescentes de Huelva. Educación, Deporte, Salud y Actividad Física ESHPA, 3(1), 95-106. DOI: http://hdl.handle.net/10481/53224

Oflu, A. y Yalcin, S. S. (2019). Uso de videojuegos en alumnos de la escuela secundaria $y$ factores asociados. Archivos Argentinos de Pediatría, 117(6), 84-91. DOI: http://dx.doi.org/10.5546/aap.2019.e584

Organización Mundial de la Salud (2019). Hacia una mejor delimitación del trastorno por uso de videojuegos. Recuperado de: https://www.who.int/bulletin/volumes/97/6/19020619/es/. 
Restrepo-Escobar, S. M., Arroyave-Taborda, L. M. y Arboleda-Sierra, W. (2019). El rendimiento escolar y el uso de videojuegos en estudiantes de básica secundaria del municipio de La Estrella- Antioquia. Educación, 43(2), 112.

DOI:

http://dx.doi.org/10.15517/revedu.v43i2.30564

Universidad Nacional Autónoma de México (UNAM) (2020). México, primer consumidor de videojuegos en américa latina. Recuperado de:

https://www.dgcs.unam.mx/boletin/bdboletin/2 020_008.html. 